
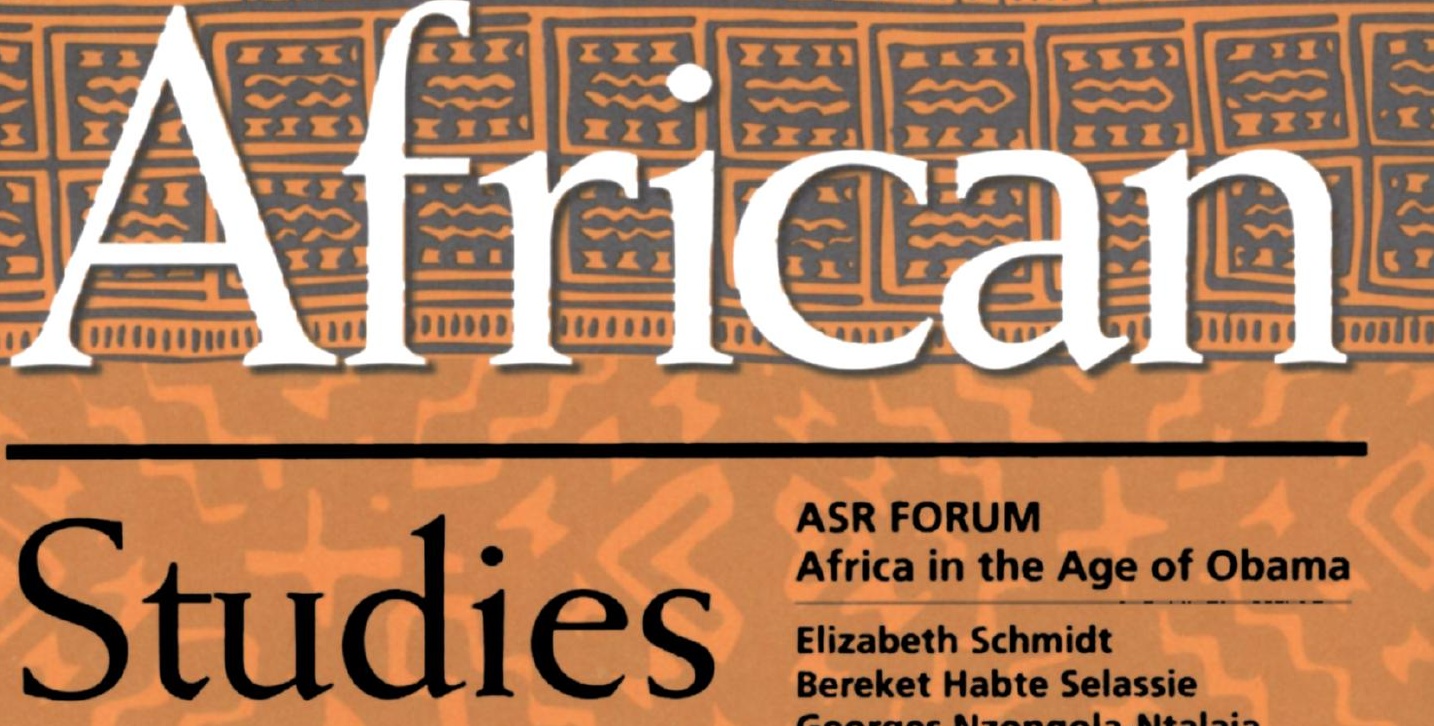

ASR FORUM

Africa in the Age of Obama

Elizabeth Schmidt

Bereket Habte Selassie

Georges Nzongola-Ntalaja

David S. Wiley

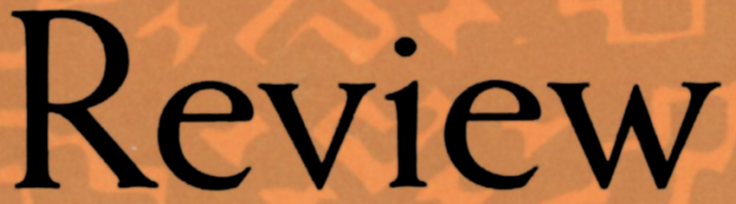

Brian Dill

Community-Based Organizations

(CBOs) and Norms of Participation

in Tanzania

Hazel McFerson

Developments in African

Governance since the Cold War

PUBLISHED BY THE AFRICAN STUDIES ASSOCIATION

\title{
David Zeitlyn
}

Diary Evidence for Political

Competition: Mambila

Autoethnography and Pretensions

to Power

\section{An Ansoms}

Views from Below on the Pro-poor Growth Challenge: The Case of Rural Rwanda

\section{Sean Redding}

Faction Fights, Student Protests, and Rebellion

José-María Muñoz

Business Visibility and Taxation in Northern Cameroon

Book Reviews 


\section{African Studies Association}

\section{The Journal of the African Studies Association}

The mission of the ASR is to publish the highest quality articles and book and film reviews in all academic disciplines that are of interest to the interdisciplinary audience of members of the African Studies Association (ASA). Manuscripts that may be of high quality but in the editors' judgment have an appeal only to a single disciplinary audience will not be considered. The editors welcome manuscript submissions from scholars everywhere, whether or not they are members of the ASA. Each manuscript is sent out to a panel of peer reviewers whose judgment the editors rely upon in deciding whether to accept the manuscript for publication.

Manuscripts and correspondence about them should be sent to the editors. A manuscript may be submitted electronically as an attachment to an e-mail message, or via the post. In the latter case, please send four copies. The peer review process proceeds more quickly for those manuscripts submitted electronically.

The ASR will only consider manuscripts for review that meet the following conditions:

- The work is submitted by its author or co-authors and not by a proxy.

- The work is original and has not been published elsewhere either in whole or in part.

- The work is not currently under consideration for publication with another journal or publisher.

Upon submitting a manuscript for editorial consideration, authors must include a statement declaring that the submission meets these conditions.

Format requirements are spelled out in the Style Guide, published in the September 2000 issue (Vol. 43, No. 2), and on the journal's Web site:

http://www.umass.edu/anthro/asr/prepare

The editing of the African Studies Review is funded by Five Colleges, Inc., a consortium representing Amherst College, Hampshire College, Mount Holyoke College, Smith College, and the University of Massachusetts Amherst.

Cover design by Craig Malone.

Cover image based on Bambara discharge-dyed mud cloth, from African Designs by Rebecca Jewell. A British Museum Pattern Book. London: British Museum Press, 1994, Plate 55. Used by permission.
Editor

Ralph Faulkingham

University of Massachusetts

Amherst

\section{Co-Editor}

Mitzi Goheen

Amherst College

\section{African Studies Review}

706 Herter Hall

161 Presidents Drive

University of Massachusetts

Amherst MA 01003

VOICE: $413-545-2065$

FAX: 413-545-9494

E-MAIL:

asr@anthro.umass.edu

WEB SITE:

http://www.umass.edu/anthro/asr

\section{Office Manager and Copy Editor}

Ella Kusnetz

\section{Production Editor \\ Craig Malone}

Books for review should be sent to the book review editors.

The African Studies

Review accepts neither unsolicited book reviews nor requests by potential reviewers to review specific books.

\section{Book Review Editor}

John Lemly

Mount Holyoke College

50 College St.

South Hadley, MA 01075

VOICE: (413) 538-2448

FAX: (413) 538-2138

EMAIL: asr-book@mtholyoke.edu 

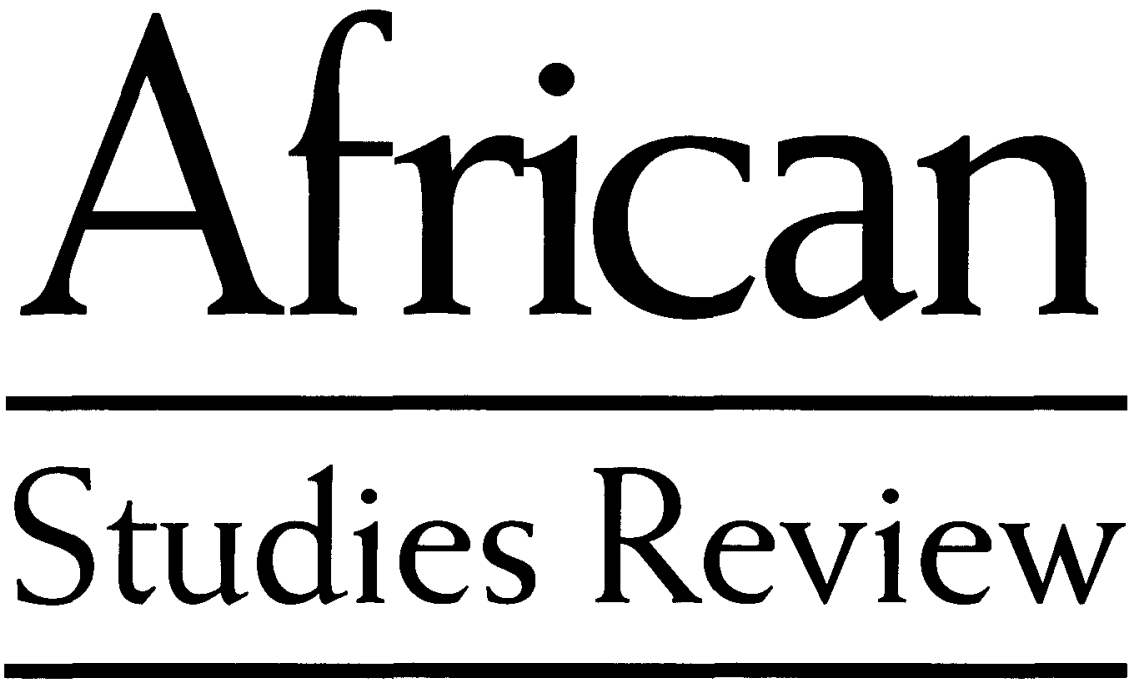

VOLUME 53, NUMBER 2

SEPTEMBER 2010

African Studies Association

Rutgers, The State University of New Jersey

Douglass Campus

132 George Street

New Brunswick, NJ 08901-1400 USA 


\section{NOTICE TO MEMBERS}

The United States Postal System does not forward periodicals. We must receive written notification from you at least five weeks in advance of any change of mailing address. Failure to notify us of your correct mailing address will result in suspension of your membership mailings until we receive such notification. We can make address changes only when current dues are paid. Domestic claims for non-receipt of issues must be made to the Association's office within six months of publication (overseas claims, one year). Copies of the Review damaged in the mail will be replaced without charge.

The African Studies Review is published three times a year (April, September, and December) by the African Studies Association, Rutgers, The State University of New Jersey, Douglass Campus, 132 George St., New Brunswick, NJ 08901-1400, USA. Articles in the Review represent neither the views of the African Studies Association nor those of its officers; responsibility for opinions expressed and for the accuracy of facts published rests solely with the individual authors.

C 2010 African Studies Association

All rights reserved.

ISSN 0002-0206

No part of this publication may be reproduced (in any form and by any means) without permission of the African Studies Association (ASA) via its registered copyright agent, Copyright Clearance Center. Information on the different types of permissions available and the associated royalties may be found online at www.copyright.com (search for African Studies Review). Once permission is secured, whether for republication in whole or in part, publishers also must acknowledge prior publication in the African Studies Review by author, title, volume, number, date, and inclusive pagination.

Authors whose works are published in ASA journals may duplicate and distribute their own works to their own classes, to their own Web sites, or to their own institution's Web site without seeking the publisher's permission, but they must cite details of publication in the specific journal by author, title, volume, number, date, and inclusive pagination.

ASA members who wish to duplicate and distribute articles published in any ASA journal for their own courses may do so without seeking permission from the ASA, but they must cite details of publication in the specific journal by author, title, volume, number, date, and inclusive pagination. 


\section{FROM THE EDITORS}

With this issue we are very pleased to welcome John Lemly as the Book Review Editor for the African Studies Review. We look forward to a long and fruitful collaboration as all the editors seek to publish the very best scholarship on Africa in our journal.

John Lemly is a professor of English and African studies and Chair of the English Department at Mount Holyoke College. From 2002 to 2006 he directed the Five College African Scholars Program with funding from the Bill and Melinda Gates Foundation. The program brought young scholars to the Five Colleges from the continent for semester-long fellowships to work on research and writing projects. Trained in British and American drama, John shifted his own professional focus after Fulbright sabbaticals in Ghana in the 1990s and more recently at the University of Fort Hare, South Africa. He writes on drama and fiction in West and southern Africa.

Ralph Faulkingham and Mitzi Goheen, Editors 


\section{African Studies Review}

VOLUME 53, NUMBER 2，SEPTEMBER 2010

\section{CONTENTS}

\section{ASR FORUM}

\section{Africa in the Age of Obama}

1 Africa in the Age of Obama

Ralph Faulkingham and Mitzi Goheen, Editors

3 Introduction

Elizabeth Schmidt

6 Can We Expect More than Symbolic Support?

Bereket Habte Selassie

12 Putting Africa's House in Order to Deal with Developmental Challenges

Georges Nzongola-Ntalaja

16 Superb Intentions and U.S. Policy Constraints David S. Wiley

\section{ARTICLES}

23 Community-Based Organizations (CBOs) and Norms of

Participation in Tanzania: Working against the Grain

Brian Dill

49 Developments in African Governance since the Cold War:

Beyond Cassandra and Pollyanna

Hazel McFerson

77 Diary Evidence for Political Competition: Mambila Autoethnography and Pretensions to Power

David Zeitlyn 
97 Views from Below on the Pro-poor Growth Challenge: The Case of Rural Rwanda

An Ansoms

125 Faction Fights, Student Protests, and Rebellion: The Politics of Beer-Drinks and Bad Food in the Transkei, South Africa, 1955-63 Sean Redding

149 Business Visibility and Taxation in Northern Cameroon José-María Muñoz

\section{BOOK REVIEWS}

\section{ANTHROPOLOGY AND SOCIOLOGY}

177 David Baronov. The African Transformation of Western Medicine and the Dynamics of Global Cultural Exchange

Michael W. Tuck

178 Steffen Jensen. Gangs, Politics and Dignity in Cape Town Erik Bähre

180 Janet Mclntosh, The Edge of Islam: Power, Personhood and EthnoReligious Boundaries on the Kenya Coast

Cynthia Brantley

181 Katherine Homewood. Ecology of African Pastoralist Societies

Peter D. Little

\section{HISTORY}

184 Christine Saidi. Women's Authority and Society in Early East-Central Africa

David Gordon

185 Daniel Branch. Defeating Mau Mau, Creating Kenya:

Counterinsurgency, Civil War and Decolonization

W. O. Maloba

187 Andrew E. Barnes. Making Headway. The Introduction of Western Civilization in Colonial Northern Nigeria

Risto Marjomaa

188 Tunde Adeleke. The Case against Afrocentrism

Gregory D. Smithers 
POLITICS, INTERNATIONAL RELATIONS, AND GLOBALIZATION

191 Cherryl Walker. Land-Marked: Land Claims and Land Restitution in South Africa

Aninka Claassens and Ben Cousins, eds. Land, Power and Custom:

Controversies Generated by South Africa's Communal Land Rights Act Lionel Cliffe

193 Steven L. Robins. From Revolution to Rights in South Africa: Social Movements, NGO's and Popular Politics after Apartheid

Phil Eidelberg

195 Roger Southall and John Daniel, eds. Zunami! The 2009 South African Elections

Howard P. Lehman

196 Filip Reyntjens. The Great African War: Congo and Regional Geopolitics, 1996-2006

Jason Stearns

199 Michael Barnett and Thomas G. Weiss, eds. Humanitarianism in Question: Politics, Power, Ethics

Beth Elise Whitaker

200 Ben Jones. Beyond the State in Rural Uganda

Michael Whyte

\section{LAW AND HUMAN RIGHTS}

204 Luc Huyse and Mark Salter, eds. Traditional Justice and Reconciliation after Violent Conflict: Learning from African Experiences

Susan Thomson

\section{GENDER}

206 Tobe Levin and Augustine H. Asaah, eds. Empathy and Rage: Female Genital Mutilation in African Literature

Ayo Kehinde

\section{ECONOMICS AND DEVELOPMENT}

208 Alula Pankhurst and Francois Piguet, eds. Moving People in Ethiopia: Development, Displacement, and the State

Astair G. M. Mengesha

\section{GEOGRAPHY, ENVIRONMENT, AND DEMOGRAPHY}

210 Camilla Toulmin. Climate Change in Africa Munyaradzi Chenje

211 Emmanuel Kreike. Deforestation and Reforestation in Namibia: The Global Consequences of Local Contradictions

Thaddeus Sunseri 


\section{RELIGION}

214 Afe Adogame, Roswith Gerloff, and Klaus Hock, eds. Christianity in Africa and the African Diaspora: The Appropriation of a Scattered Heritage

Ludovic Lado

216 Abel Ugba. Shades of Belonging: African Pentecostals in Twenty-First Century Ireland Jane Soothill

\section{LANGUAGES, LITERATURE, AND ARTS}

218 Mwenda Ntarangwi. East African Hip Hop: Youth, Culture and Globalization George Gathigi

219 Bernth Lindfors. Early Soyinka Obi Maduakor

221 Leonard Kahan, Donna Page, and Pascal Imperato, eds. Surfaces: Color, Substances, and Ritual Applications on African Sculpture Mary Jo Arnoldi

\section{MEMOIRS AND BIOGRAPHY}

223 Jeremy Gordin. Zuma: A Biography Hlonipha Mokoena

224 Marie-Pierre Ulloa. Francis Jeanson: A Dissident Intellectual from the French Resistance to the Algerian War Phillip C. Naylor 